Małgorzata Marmola*, PhD, https://orcid.org/0000-0003-2915-8891

Danuta Ochojska*, PhD, https:/ / orcid.org/0000-0002-0535-1884

Anna Wańczyk-Welc*, PhD, https:/ / orcid.org/0000-0002-4743-1049

* Department of Psychology

Institute of Pedagogy, University of Rzeszów

\title{
The quality of communication between spouses raised in nuclear and single-parent families
}

\author{
Poziom komunikowania się u małżonków pochodzących \\ $\mathrm{z}$ rodzin pełnych i niepełnych ${ }^{1}$ \\ https://doi.org/10.34766/ fetr.v47i3.889
}

\begin{abstract}
The article concerns marriage communication among husbands and wives raised in nuclear and single-parent families. Marital communication is a crucial factor determining the quality and stability of marriage. Moreover, communicating spouses are a source of role models for their children. Research on a sample of 296 participants (148 couples) using the Communication in Marriage Questionnaire (KKM) by Mieczyslaw Plopa and Maria Kaźmierczak indicates irregularities in communication between spouses raised in single-parent families. Dysfunctional communication in marriage mainly consists in low commitment to communication with the spouse and a high level of depreciation.
\end{abstract}

Keywords: marriage communication, nuclear families, single-parent families, quality of marriage

Abstract: Artykuł dotyczy komunikacji w małżeństwie u mężów i żon pochodzących z rodzin pełnych i niepełnych. Zagadnienie komunikacji $\mathrm{w}$ małżeństwie jest istotnym czynnikiem warunkującym jakość małżeństwa i jego trwałość, ale także komunikujący się małżonkowie są źródłem wzorców dla swoich dzieci. Badania przeprowadzone w grupie 296 osób (148 par małżeńskich) za pomocą Kwestionariusza Komunikacji Małżeńskiej KKM Mieczysława Plopy i Marii Kaźmierczak wskazują na nieprawidłowości w komunikowaniu się wśród małżonków pochodzących $\mathrm{z}$ rodzin niepełnych. Dysfunkcje $\mathrm{w}$ komunikacji małżeńskiej dotyczą głównie niskiego poziomu zaangażowania $\mathrm{w}$ komunikację $\mathrm{z}$ partnerem oraz wysokiego poziomu deprecjacji.

Słowa kluczowe: komunikacja w małżeństwie, jakość małżeństwa, rodziny pełne, rodziny niepełne

\section{Introduction}

In every marriage there has to be communication concerning both important and everyday matters. It not only serves the purpose of information exchange between husband and wife but also impacts the quality of the relationship. An important task for spouses is to establish a pattern of communication that will enable mutual understanding and the

\footnotetext{
${ }^{1}$ Polska wersja: https:// stowarzyszeniefidesetratio.pl/Presentations0/2021-3-Marm.pdf
} 
experience of intimacy. One may ask at this point: To what extent is this pattern related to their experience in their families of origin? Do the interaction patterns found in families of origin impact on the marital communication of grown-up children raised in those families? Are young people raised in single-parent and broken families, in which they did not have the opportunity to observe everyday communication between mother and father, capable of communicating with their spouses in a satisfactory manner? The present article is a reflection on these issues.

\section{The Family System}

Family is the first, basic, and essential life environment for every person (Jakubiak \& Nawrot-Borowska, 2016; Wolska-Długosz, 2016, Strużyńska, 2020). It satisfies important needs and helps accomplish important life tasks, thus increasing self-esteem; it also shapes the adolescent child's sense of identity. It is in the family that behavior patterns develop and that specific views and attitudes are assimilated. Family is a source of principles and behavior patterns for children (Brzezińska, Appelt, \& Ziółkowska, 2016; Ostafińska-Molik \& Wysocka, 2016; Zalewska, 2017). More and more often, family is considered as a system with its own norms and rules and a variety of measures to maintain its coherence; it is, moreover, seen as a system that has specific goals and specific ways of satisfying the needs of its members (Jankowska, 2016; Ryś, 2001; Segal, Qualls, \& Smyer, 2018).

The family system is an organized composition of elements that make up a coherent whole (Bajkowski, 2017; Drożdżowicz, 2020), and a change in any of its components influences the remaining ones (attesting to its holistic nature). The elements of the system are interrelated, and circular causality creates a feedback loop, making it possible for someone or something to be both a cause and an effect of specific behaviors (Józefik, 2020; Margasiński, 2015; Rostowska, 2008). The individuals who make up a family are dependent on one another, share a common history, and are bound by emotional ties (Plopa \& Połomski, 2010). Family members together make up a network of interrelations. Each of them is an individual person and at the same time bears the marks of the whole system (Ryś, 2001; Wampler \& Patterson, 2020). A family is a whole, and changes concerning any of its elements influence the remaining ones. A change of internal or external conditions forces the entire family system to engage in adaptive actions, enabling proper functioning. This is the case, for example, when the parents separate or divorce or/and when a new family member is adopted, or when a close family member dies. Such events may bring about profound changes to the functioning of the remaining individuals in the family, considered as a whole. The more the loss or gain in a situation of family breakdown or reconstruction concerns the parents, who constitute the central subsystem, the greater the changes of this kind. The 
existing behavior pattern is upset and a new one is sought, better suited to the current conditions (Grzesiuk \& Jakubowska, 2005; Walęcka-Matyja \& Janicka, 2021).

The family system consists of hierarchically organized subsystems (Drożdżowicz, 2020; Franczyk, 2021). The basic subsystems within the family are the marital, parental, and sibling subsystems (Bocakova \& Kubickova, 2013; Rostowska, 2008).

The main relationship in the family system is the marital relationship (BraunGałkowska, 1992; Weryszko, 2020), which is why the married couple are sometimes called "the architects of the family" (Satir, 2000), and their sense of marital happiness impacts on their satisfaction with the family and overall satisfaction with life. What plays an important role in building a satisfying marital relationship is communication between the spouses, including the ability to resolve conflicts. The marital subsystem must learn cooperation and at the same time tolerance of each other's differences and independence (de Barbaro, 2020). High marriage quality in other dimensions also facilitates the constructive resolution of difficult situations, which means the relation functions as a feedback loop (Nurhayati, Faturochman, \& Helmi, 2019; Weryszko, 2020).

\section{The Communication Process}

Communication is a complex process that concerns people interacting with one another. It takes place on different levels and varies in scope, from direct "face-to-face" communication between individuals, through communication in a group, to mass communication using complex media and channels, such as the Internet or television (Ogonowska, 2018). According to DeVito (2019), communication is dyadic, which means it takes place between two people who are bound by an established relationship. Accordingly, communication takes place between two siblings, between the spouses, between an employer and an employee, or between a teacher and a student. Matthew McKay, Martha Davis, and Patrick Fanning (2019) point out that effective communication is a basic life skill, building and maintaining relationships with others.

Communication can also be seen as a process consisting in information exchange by means of symbols. The symbols in this exchange are used in the form of words and various nonverbal indicators (Kaźmierczak \& Plopa, 2008; cf. Beattie \& Ellis, 2017). Accordingly, communication means the flow of information between the sender and the receiver-in an act of communication, the sender transfers content through some kind of channel to the receiver, whom this content is supposed to influence in a particular way (Jankowska, 2016). Interpersonal communication is based on individual interpretation of messages and takes place in a specific context, which means the same information transferred in a different situation may be interpreted differently (DeVito, 2019). In this process there are always factors that hinder the sending and reception of contents, referred to as information noise, 
which may considerably distort the information being communicated and sometimes even make it totally incomprehensible. The reception of a message is confirmed by the receiver's answer or by the commencement of a particular action upon receiving the message-namely, feedback. Feedback is very important in every act of interpersonal communication, particularly in close relationships-for instance, in communication between spouses (Jankowska, 2016).

Every person develops their own unique style of communicating with others, referred to as conversational style (Tannen, 1986). It reveals the manner of coding or shaping the message. It also impacts on other people's ways (direct or indirect) of coding and interpreting the information received. The greater the self-awareness, the greater the ability to communicate clearly and directly. What is also of considerable significance is self-esteem, as it is related to the communicating partners' tendency to be frank.

Moreover, the consistency of message is also highly important in the process of communicating. One can speak of consistency when different components of this process convey the same meaning. The level of consistency is determined by the conversational styles in the family of origin (Galvin, Braithwaite, \& Bylund, 2015).

Describing the gender aspect of the communication process, Judy C. Pearson, Richard West, and Lynn Turner (1995) suggest that differences in this respect are not so large as they are commonly reported to be. However, according to Deborah Tannen (1990), while women seek such forms of communication that encourage others to engage, men stress autonomy and power. Women are more willing than men to communicate in a less firm and more socially sensitive manner, while men are more willing to provide suggestions, opinions, and information (Anderson \& Sabatelli, 1999). Men more readily interrupt others and take control of the conversation, particularly with a woman. Women more often use an indirect style (Tench, Topić, \& Moreno, 2017); they are more sensitive to emotional messages, and formulate requests or suggestions more delicately (Mulac, 2009). Accordingly, women are oriented towards emotionality and building relationships, and their communication is characterized by greater expressiveness; men, by contrast, build vertical relations, and communication serves them to climb the ladder of social hierarchy - to position themselves as leaders or experts appraising reality rationally (Osior-Szot, 2018).

\section{Communication in Marriage}

In the system of communication in close relationships all behaviors are a form of communication; in other words, there is no situation in which nothing is communicated (Plopa, 2008). In marriage there should be communication concerning both important and everyday matters. Communication not only serves the purpose of information exchange but also significantly impacts on the quality of the relationship (cf. Khezri, Hassam, \& Nordin, 
2020). Ronald Adler, Lawrence Rosenfeld, and Russel Proctor (2018) report that the lack of effective communication contributes to the severing of the marital bond and to the breakdown of marriage much more often than other factors. What also plays an important role is the elimination of barriers to communication, which allows for enhancing the sense of security and mutual respect (Wróbel, 2021). The effectiveness of the marital communication system depends on clear and comprehensible messages received from each partner; therefore, an important task for the spouses is to establish a communication pattern that will enable mutual understanding and the experience of intimacy. The family is thus built through communication, and a shared narrative contributes to the maintenance of balance and harmonious relations (Segrin \& Flora, 2019); it also positively influences the successful performance of the tasks set by the family system (Duda, 2017).

Given that marriage is a unique intimate relationship, communication in this case does not merely consist in interacting; its essential goal is also to support intimacy. It should therefore convey messages to the partner that give him or her a sense of being respected and valued. Intimacy between spouses may concern both the emotional sphere and the intellectual and actional spheres. Emotional intimacy manifests itself in mutual care, sensitivity, tenderness, and empathizing with each other's mental states. Its effect is a sense of security, acceptance, and support-one might say, a sense of happiness that releases human activity (Ryś, 2004). Another element that proves to be significant here is having what can be called a common code, openness to others, and communicating one's feelings, both positive and negative ones. The essence of intellectual intimacy consists in seeking a mutual exchange of experiences and reflections, which facilitates solving problems and treating the spouse as one's equal, a person with their own needs and goals (Ryś, 2004). Actional intimacy manifests itself in common strivings, in shared responsibility for the actions undertaken, and in overcoming obstacles together. It helps in the fulfillment of tasks associated with marriage and parenthood and in the partners' personal growth. Cooperation reinforces friendship between the spouses, thereby contributing to greater satisfaction with the marital relationship (Braun-Gałkowska, 1992; Ryś, 2004).

Mieczysław Plopa (2008) distinguishes three types of marital communication (all three take place simultaneously, and their levels determine the quality of communication between spouses): (1) supportive communication, which conveys appreciation and joy at the partner's existence, the recognition of the partner as a valuable person, and the approval of their ways of expressing themselves; it manifests itself in respect, openness, and interest in the needs and problems of the spouse; (2) committed communication, which highlights the spouses' closeness with each other and the uniqueness of the marital relationship, presupposing the ability to create a warm and intimate atmosphere, efforts to make the partner happy and prevent routine, and the disclosure of personal information about oneself so that the spouses can get to know each other better, develop mutual understanding, and 
learn each other's thoughts and expectations; (3) communication depreciating the spouse, which results in the partners drifting apart; it is characterized by aggressive behavior, lack of respect for the other person's dignity (insults, arrogant behavior), and a desire to dominate and control the spouse.

Various difficulties appear in marital communication. Some of them stem from the content of messages or from the interlocutors' individual conversational characteristics (DeVito, 2019). Open contact with the other person is hindered by a sense of uncertainty, rooted in low self-esteem. Another difficulty in communication between spouses is the different nature of their psyche. Women's approach to married life is more emotional, while men's approach is more rational (Celmer, 1989). Married couples dissatisfied with their relationship show a tendency to reciprocate negative messages (Tryjarska, 2003). Research shows that the communication of negative contents is found more often among couples dissatisfied with marriage than among satisfied ones. This means communication is ineffective if it is criticism that dominates in messages to the spouse (Weryszko, 2020).

A significant component of marital communication is resolving conflicts-coping with situations that involve a clash of opposing views, aspirations, desires, or expectations. Most conflicts and misunderstandings stem from communication difficulties, particularly from the inability to identify one's own and the partner's needs and psychological characteristics and from the inability to send and receive messages. The research conducted by Aleksandra Szczęsna and Hanna Przybyła-Basista (2019) showed that men experiencing conflict situations found it more difficult than women to talk about problems openly or to come into close physical contact with their partner. They found it much easier to engage in specific actions to improve the functioning of the relationship (e.g., shared meals, shopping, or taking care of the partner's health). What women expected from men was support in the form of frank verbal and nonverbal communication. Thus, the messages communicated can either build or ruin the relationship. Resolving conflict situations constructively can contribute to an increase in self-knowledge and an enhancement of personal autonomy, thus strengthening cohesion in marriage. A conflict of this kind usually concerns facts; it does not strike at the partner's dignity and is not meant to hurt him or her; the emotions about current events are expressed in an honest and straightforward way. Communication in such situations is clear and transparent, and verbal messages are consistent with nonverbal ones.

Unfortunately, some conflicts lead to the disintegration of the relationship. They often concern speculations, conjectures, or fantasies, and spouses hurt each other by using unpleasant epithets. It sometimes happens that one of the partners shows disrespect to and humiliates the other, in which case commitment to the resolution of conflict is one-sided. This is where first contradictory messages appear, which leads to irritation or a sense of helplessness (Ryś, 2004). 


\section{Single-Parent Families}

The original understanding of family was associated with relationships of consanguinity and included people linked by blood relationships or affinity; this is reflected in the structural definition, according to which "a family is composed of at least one parent and one child who are biologically related to each other and share a common place of residence" (Slany, 2002, p. 79). Considering the completeness of structure, Natalia HanIlgiewicz (1995, as cited in Koprowicz, Gumowska, \& Piotrów, 2018) distinguished the following types of families: nuclear, single-parent (an unmarried mother with a child), incomplete (as a result of mother's or father's death), broken (left by mother or father), and reconstructed (including a stepfather, a stepmother, or an adopted child). In the Polish literature on family issues one can observe the view that the social norm is a nuclear family, which is a model of family based on indissoluble marriage, composed of parents and children (Walęcka-Matyja, 2014; Wilk, 2016). The lack of some personal components in this composition results in the incompleteness of the family structure. The terms proposed by scholars to refer to family structures other than nuclear point to difficulties or problems in the functioning of such families (Burkacka, 2017), for instance: broken families, dysfunctional families, fatherless families, or unmarried motherhood.

A family can be called a single-parent family when only one of the parents lives together with the children and takes care of them (Burkacka, 2017; Krasiejko, 2018). The causes behind the emergence of such families are diverse: from conscious decision to be a single mother, through the spouse's death, to divorce, separation, or informal break-up of the spouses and to migrations (Wolska-Długosz, 2016). Recent years in Poland have witnessed a consistent increase in the proportion of extramarital births in the total number of births and an increase in divorce rate. This has resulted in an increase in the number of single-parent families; such families constituted $11.0 \%$ of families raising children up to 16 years of age in 2010, which increased to $15.4 \%$ by 2019 (GUS, 2020). Among single-parent families the dominant model is a mother raising children on her own-such families account for $19.4 \%$ of Polish families (single fathers account for $2.8 \%$ ). The causes of the current increase in the number of single mothers lie not so much in the spouse's death as in the increasing number of alternative forms of family life and in the processes of family disorganization that end up in divorce or separation. These factors lead to an increase in the number of extramarital births and to one parent, usually the mother, taking charge of the child (Marek-Zborowska, 2016). These families deserve attention because they struggle with various problems that concern the financial sphere on the one hand (lower income, with one person having to provide for the family; Kalinowski, Jabłońska-Porzuczek, 2016) and the 
psychosocial sphere on the other. Raising a child on one's own is also a source of parental stress.

The cause of single parenthood can be divorce, the spouse's death or permanent absence, or children being born out of wedlock (Burkacka, 2017). A single-parent family is thus a characteristic type of structure in which parental tasks are performed by one parent and in which relations with the caregiving parent dominate in the child's life (Gawda, 2018).

The term "incomplete family" is also sometimes used to refer to those families in which both parents are lacking and the children are brought up by their older siblings, grandparents, or relatives, or to families with two parents in which one of the parents does not perform the tasks involved in parental duties due to work at a location distant from the place of residence (e.g., a sailor; Nowak, 2018).

A broken family is considered a type of single-parent or incomplete family, with emphasis placed on the fact that it is a family that failed in terms stability and is devoid of the presence of one or both parents as a result of separation or divorce (Szewczuk, 2010). In such cases, the child has to cope with the loss of a stable family that used to give a sense of security and with the absence of one of the parents in everyday life. Unfortunately, the child often witnesses pathological communication between the parents before and during divorce; he or she may also be used by one of the parents as a weapon against the other. Adaptation to the new life comes with time, but the stress associated with parents' divorce may have farreaching consequences concerning, for instance, self-esteem or the ability to enter into relations with others (Brągiel, 2017; Olearczyk, 2008).

More and more often, children are brought up in so-called binuclear families, ones with two nuclei, where divorced or informally separated parents engage in raising their child to an equal degree. This means the child has two homes: mother's and father's (Burkacka, 2017).

The category of single-parent or incomplete families can be seen as including also nomadic (itinerant, visit-based) families - namely, the increasingly frequent situations in which the family functions only for some time because one of its members (usually the father) works far from home, and the children and the spouses see one another only during leaves or weekends and usually maintain their relationship via Internet connections. Upbringing in this kind of family resembles the functioning of a broken family. Such families account for approximately 4\% of all families in Poland (Burkacka, 2017; Molesztak, 2017).

Both a nuclear family and a single-parent family may be an environment conducive to children's development, or the fulfillment of care and educational tasks may be threatened there. A single-parent family may struggle with difficulties in satisfying basic economic needs; it may also limit its educational and socializing functions-for example, due to the lack of identification of the father with the son. Problems may concern the single mother's authority, father's contacts with children during separation, or disciplining the children (e.g., 
a greater number of corporal punishments administered to sons). Single mothers may experience anxiety and fear, and they may tighten their relations with the child in order to compensate him or her for the father's absence. The situation of these families should not be generalized, however (Kuzdak, 2018; Matyjas, 2015; Wolska-Długosz, 2016).

Changes in the family structure undoubtedly modify the conditions of fulfilling parental functions and, consequently, the conditions of children's development and upbringing (McKay, Davis, Fanning, 2019). It is therefore reasonable to assume that adolescents' development and preparation for adulthood in single-parent families proceeds differently than it does in nuclear families (Parzątka-Lipińska, 2019). This, however, does not justify the opinion that a single-parent family fails to ensure an atmosphere favorable to upbringing and does not give children a chance for harmonious development. When one of the parents is missing in the family, the child's development is modified-due to incomplete intergenerational transmission, among other reasons. Growing up in a single-parent family, a young person does not receive all the necessary patterns of symbolization, evaluation, and categorization of experience, which impedes psychological functioning and the competent resolution of developmental tasks (Danielewicz-Mucha, 1995). The research conducted by Hanna Liberska (1998) showed the similarity of the systems of values of young people raised in nuclear families and those raised in single-parent families, but there were certain differences between these two groups in the hierarchy of values. In the preferences of adolescents brought up in single-parent families emphasis is placed on values associated with career and with moral and religious development, whereas for adolescents raised in nuclear families the most important values are those associated with social life and strong interpersonal ties, such as marriage, friendship, sociopolitical engagement, and the material sphere. Young people from the latter group combine aspirations oriented to family happiness and material welfare with engagement in the functioning of broader communities, while young people from single-parent families tend to be oriented towards their own professional and spiritual development. The system of values functioning in both groups of adolescents reflects the values commonly accepted in our culture, which means both nuclear and single-parent families create conditions for boys and girls to fulfill the developmental task of forming a system of values and, on this basis, to form a framework of life plans for the future. Also optimistic is the result showing that in difficult situations young people from both backgrounds tend to choose rational strategies. This portends well for the efficiency of functioning, both in adolescence and in the subsequent periods of life. Regardless of the family background, contemporary adolescents have relatively good well-being, high selfesteem, and positive attitudes to life. Liberska stresses that the group which has more favorable conditions for development is boys and girls raised in nuclear families, whom mothers provide with conditions for developing positive self-esteem and whose positive attitude towards their personal future has a greater chance to develop thanks to the father. 
Basically, however, research results does not support the fears that a single-parent family is incapable of securing the proper functioning and development of adolescent children.

The research conducted by Bożena Matyjas (2015) revealed a complex picture of children raised in single-parent families. Half of the participants experienced a developmentally unfavorable home atmosphere of distrust, conflicts, excessive demands, severity, and criticism. The loneliness of the children in this group stems from disturbances regarding emotional bonds. The participants maintained positive relations with their siblings, who were quite often the only support for them. Disturbed emotional relations in the family lead to the development of negative behaviors that interfere with proper acceptance in the peer group, thus causing rejection and growing loneliness; this in turn may lead to lasting destructive changes and to problems in adult life (Przybysz-Zaremba, 2017).

\section{Intergenerational Transmission}

Intergenerational transmission is the transfer of psychophysical characteristics between parents and children, involving the biological and social environment. It is described as a kind of generational continuity regarding behavior patterns that result from an individual being part of and spending time with the family (Farnicka, 2016). The handing down of values in the family takes place thanks to two processes. The first of these concerns the marital relationship and consists in the modification of values as a result of mutual influences (through a mechanism referred to as the alignment of values, which is related to interpersonal attractiveness). The second process is associated with handing down values to the generation of children through social inheritance. This takes place directly -in the form of parents' intentional educational interventions (the modeling, identification, and shaping of the semantic structure of children's concepts by parents) - or indirectly, in the form of channels for incorporating values into the structure of children's personality through parental attitudes, emotional climate, and the satisfaction of psychological needs (Elżanowska, 2012).

According to Małgorzata Sitarczyk (1995) what plays the key role in intergenerational transmission is individual experiences, mainly those from early childhood (the events, situations, and contacts with the environment that provide stimulation and serve as the basis for further development), and family life factors, such as social imitation, identification, and modeling. Performing specific roles, parents provide their children with models, which means everyday contacts with the parents, observing how they pursue the values they have recognized as important in their life, and encouragement to live by these values make it possible for the children to internalize them and adopt them as their own.

The experiences from the family of origin, concerning socialization, position in the family, and interactions with mother and father, impact on young adults' interactions in 
close relationships and on their preferences associated with upbringing, decision making, or exercising power. The research conducted by Paul Schrodt and Xavier Scruggs (2020) indicates that the family also provides family communication patterns. The transmission of various aspects of functioning from the family of origin into the family of procreation makes it possible to understand young adults' ways of functioning in marital and parental roles (Plopa, 2008).

\section{Methodological Assumptions of the Present Study}

The subject of the research presented in this article was the quality of marital communication in men and women raised in nuclear and single-parent families.

The study was meant to answer the following questions:

1) What are the levels of support, commitment, and depreciation shown to the spouse by husbands and wives raised in nuclear families?

2) What are the levels of support, commitment, and depreciation shown to the spouse by husbands and wives raised in single-parent families?

3) What are the levels of support, commitment, and depreciation experienced from the spouse by husbands and wives raised in nuclear families?

4) What are the levels of support, commitment, and depreciation experienced from the spouse by husbands and wives raised in single-parent families?

5) Are there differences in the levels of support, commitment, and depreciation shown to the spouse between individuals raised in nuclear families and those raised in single-parent families?

6) Are there differences in the levels of support, commitment, and depreciation experienced from the spouse between individuals raised in nuclear families and those raised in single-parent families?

We conducted the study using the Communication in Marriage Questionnaire (KKM), developed by Maria Kaźmierczak and Mieczysław Plopa (2008). The questionnaire comes in two versions: one for measuring self-reported behaviors and the other for rating behaviors experienced from the partner. Each version consists of 30 items and yields scores on three dimensions: Support, Commitment, and Depreciation.

Support is defined as showing respect to one's partner by appreciating their efforts, showing interest in their problems and needs, and solving problems together. Commitment is the ability to create an atmosphere of mutual understanding and intimacy, showing feelings to each other, highlighting the importance and uniqueness of the partner, adding variety to the daily routine, and preventing conflicts. Depreciation means showing aggression towards the partner, a desire to dominate the partner and control their actions, and a lack of respect for their dignity. 
The participants were married people in their young adulthood, aged 22 to 35 years, bringing up at least one preschool child. We distinguished two groups among them:

1) Married people raised in nuclear families: 144 participants, 72 men and 72 women.

2) Married people raised in single-parent families: 104 participants, 52 men and 52 women.

\section{Results}

In the statistical analysis of research results we used arithmetical means, standard deviations, and Student's t-test to compute differences between the groups.

The Table 1 presents data concerning the behaviors self-reported by spouses raised in nuclear families.

Table 1. Self-Reported Behaviors of Spouses Raised in Nuclear Families: Differences Between Men and Women

\begin{tabular}{|c|c|c|c|c|c|c|c|c|}
\hline \multirow[b]{2}{*}{ KKM scales } & \multicolumn{2}{|c|}{ Men } & \multicolumn{2}{|c|}{ Women } & \multicolumn{2}{|c|}{ Total sample } & \multirow{2}{*}{$\begin{array}{c}\text { Student's } \\
t\end{array}$} & \multirow[t]{2}{*}{$\mathrm{CL}$} \\
\hline & $M$ & $S D$ & $M$ & $S D$ & $M$ & $S D$ & & \\
\hline \multirow{2}{*}{$\begin{array}{l}\text { Support - RS } \\
\text { Sten scores }\end{array}$} & 40.51 & \multirow[t]{2}{*}{5.97} & 41.82 & \multirow[t]{2}{*}{5.82} & 41.26 & \multirow[t]{2}{*}{5.91} & \multirow[t]{2}{*}{-1.32} & \multirow[t]{2}{*}{.09} \\
\hline & sten 6 & & sten 6 & & sten 6 & & & \\
\hline \multirow{2}{*}{$\begin{array}{l}\text { Commitment - RS } \\
\text { Sten scores }\end{array}$} & 31.00 & \multirow[t]{2}{*}{6.17} & 33.17 & \multirow[t]{2}{*}{8.56} & 32.24 & \multirow[t]{2}{*}{7.68} & \multirow[t]{2}{*}{1.69} & \multirow[t]{2}{*}{.04} \\
\hline & sten 5 & & sten 6 & & $\begin{array}{l}\text { sten } \\
5 / 6\end{array}$ & & & \\
\hline \multirow{2}{*}{$\begin{array}{l}\text { Depreciation - RS } \\
\text { Sten scores }\end{array}$} & 23.51 & \multirow[t]{2}{*}{9.34} & 22.68 & \multirow[t]{2}{*}{9.90} & 23.04 & \multirow[t]{2}{*}{9.64} & \multirow[t]{2}{*}{0.51} & \multirow[t]{2}{*}{.30} \\
\hline & sten 6 & & sten 6 & & sten 6 & & & \\
\hline
\end{tabular}

Note. $M=$ arithmetic mean; $S D$ = standard deviation; $\mathrm{CL}$ = confidence level; $\mathrm{RS}$ = raw score.

Source: authors' research.

One can observe that, in fact, all scores of spouses raised in single-parent families are medium.

Analysis shows that there was one statistically significant difference at .05 between men and women in commitment-namely, men rated their commitment to the relationship lower than women rated theirs.

The next Table 2 present the scores of spouses raised in single-parent families. 
Table 2. Self-Reported Behaviors of Spouses Raised in Single-Parent Families: Differences Between Men and Women

\begin{tabular}{|c|c|c|c|c|c|c|c|c|}
\hline \multirow[b]{2}{*}{ KKM scales } & \multicolumn{2}{|c|}{ Men } & \multicolumn{2}{|c|}{ Women } & \multicolumn{2}{|c|}{ Total sample } & \multirow{2}{*}{$\begin{array}{c}\text { Student's } \\
t\end{array}$} & \multirow[t]{2}{*}{ CL } \\
\hline & $M$ & $S D$ & $M$ & $S D$ & $M$ & $S D$ & & \\
\hline \multirow{2}{*}{$\begin{array}{l}\text { Support - RS } \\
\text { Sten scores }\end{array}$} & 38.2 & \multirow[t]{2}{*}{9.57} & 42.0 & \multirow[t]{2}{*}{5.03} & 39.9 & \multirow[t]{2}{*}{8.07} & \multirow[t]{2}{*}{-2.27} & \multirow[t]{2}{*}{.01} \\
\hline & sten 5 & & sten 6 & & sten 5 & & & \\
\hline \multirow{2}{*}{$\begin{array}{l}\text { Commitment - RS } \\
\text { Sten scores }\end{array}$} & 29.9 & \multirow[t]{2}{*}{7.49} & 30.5 & \multirow[t]{2}{*}{6.05} & 30.17 & \multirow[t]{2}{*}{6.86} & \multirow[t]{2}{*}{-0.43} & \multirow[t]{2}{*}{.33} \\
\hline & sten 4 & & sten 5 & & sten 5 & & & \\
\hline \multirow{2}{*}{$\begin{array}{l}\text { Depreciation - RS } \\
\text { Sten scores }\end{array}$} & 24.4 & \multirow[t]{2}{*}{6.88} & 21.5 & \multirow[t]{2}{*}{6.01} & 23.11 & \multirow[t]{2}{*}{6.64} & \multirow[t]{2}{*}{2.1} & \multirow[t]{2}{*}{.02} \\
\hline & sten 6 & & sten 5 & & sten 6 & & & \\
\hline
\end{tabular}

Note. $M=$ arithmetic mean; $S D=$ standard deviation; $\mathrm{CL}=$ confidence level; $\mathrm{RS}=$ raw score. Source: authors' research

As in the case of spouses brought up in nuclear families, all scores of those raised in single-parent families were medium, except the score on commitment, which was low (i.e., men rated their level of commitment to the relationship as low).

The scores were the highest on depreciation (sten 6 for the whole group), particularly in men (sten 6) - they indicate a tendency to depreciate their wives. Women scored equally high on support (sten 6), which indicates a high level of support given to the partner.

Men's commitment scores were at the level of sten 4, which may stem from the lack of openness to communication with the spouse in the male subgroup. Significant differences between men and women raised in nuclear families were found in support (higher in women; $\mathrm{t}=-2.27, \mathrm{p}<.01$ ) and depreciation (higher in men; $\mathrm{t}=2.1, \mathrm{p}<.02$ ).

Table 3. Differences in Self-Reported Behaviors Between Spouses Raised in Nuclear and Single-Parent Families

\begin{tabular}{|c|c|c|c|c|c|c|c|}
\hline \multirow[t]{2}{*}{ Group } & \multirow[b]{2}{*}{ KKM scales } & \multicolumn{2}{|c|}{ Nuclear families } & \multicolumn{2}{|c|}{ Single-parent families } & \multirow[b]{2}{*}{$\begin{array}{c}\text { Student's } \\
t\end{array}$} & \multirow[b]{2}{*}{ CL } \\
\hline & & $M$ & $S D$ & $M$ & $S D$ & & \\
\hline \multirow{3}{*}{$\sum_{\Sigma}^{\tilde{d}}$} & Support & 40.51 & 5.98 & 38.2 & 9.57 & 1.67 & .05 \\
\hline & Commitment & 31.0 & 6.17 & 29.9 & 7.49 & 0.85 & .19 \\
\hline & Depreciation & 23.52 & 9.34 & 24.4 & 6.88 & -0.55 & .29 \\
\hline \multirow{3}{*}{$\begin{array}{l}\text { ఖี } \\
\text { है } \\
3\end{array}$} & Support & 41.83 & 5.82 & 42.0 & 5.04 & -0.15 & .43 \\
\hline & Commitment & 33.17 & 8.57 & 30.5 & 6.55 & 1.76 & .04 \\
\hline & Depreciation & 22.68 & 9.90 & 21.5 & 6.01 & 0.69 & .24 \\
\hline \multirow{3}{*}{ 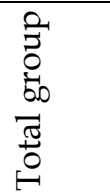 } & Support & 41.26 & 5.91 & 39.9 & 8.07 & 1.71 & .05 \\
\hline & Commitment & 32.24 & 7.68 & 30.17 & 6.86 & 2.08 & .02 \\
\hline & Depreciation & 23.04 & 9.64 & 23.11 & 6.64 & -0.06 & .47 \\
\hline
\end{tabular}

Note. $M=$ arithmetic mean; $S D$ = standard deviation; $\mathrm{CL}=$ confidence level. Source: authors' research. 
The comparison of total groups raised in nuclear and single-parent families revealed significant differences in the levels of support $(t=1.71, p<.05)$ and commitment $(t=2.08, p$ $<.02)$, which were higher in spouses brought up in nuclear families.

The comparison of men raised in nuclear and single-parent families revealed a significant difference in the level of support for wives $(t=1.67, \mathrm{p}<.05)$, which was higher in men raised in nuclear families. The comparison of women's scores in the two groups showed a significant difference in the level of commitment $(t=1.76, p<.04)$, which was also higher in women raised in nuclear families.

Regarding spouses brought up in nuclear families, the wives were more committed to marital communication, while the husbands were more supportive towards them, which means in their families there is a greater probability of satisfying relations than in the case of spouses raised in single-parent families.

Table 4. Evaluation of Partner Behaviors by Spouses Raised in Nuclear Families: Differences Between Men and Women

\begin{tabular}{|c|c|c|c|c|c|c|c|c|}
\hline \multirow[b]{2}{*}{ KKM scales } & \multicolumn{2}{|c|}{ Men } & \multicolumn{2}{|c|}{ Women } & \multicolumn{2}{|c|}{ Total sample } & \multirow{2}{*}{$\begin{array}{c}\text { Student's } \\
t\end{array}$} & \multirow[t]{2}{*}{$\mathrm{CL}$} \\
\hline & $M$ & $S D$ & $M$ & $S D$ & $M$ & $S D$ & & \\
\hline \multirow{2}{*}{$\begin{array}{l}\text { Support - RS } \\
\text { Sten scores }\end{array}$} & 39.21 & \multirow[t]{2}{*}{7.51} & 41.28 & \multirow[t]{2}{*}{7.48} & 40.32 & \multirow[t]{2}{*}{7.54} & \multirow[t]{2}{*}{-1.67} & \multirow[t]{2}{*}{.05} \\
\hline & sten 5 & & sten 6 & & sten 5 & & & \\
\hline \multirow{2}{*}{$\begin{array}{l}\text { Commitment - RS } \\
\text { Sten scores }\end{array}$} & 27.12 & \multirow[t]{2}{*}{5.02} & 27.53 & \multirow[t]{2}{*}{4.88} & 27.34 & \multirow[t]{2}{*}{4.94} & \multirow[t]{2}{*}{-0.49} & \multirow[t]{2}{*}{.31} \\
\hline & sten 4 & & sten 4 & & sten 4 & & & \\
\hline \multirow{2}{*}{$\begin{array}{l}\text { Depreciation - RS } \\
\text { Sten scores }\end{array}$} & 26.21 & \multirow[t]{2}{*}{7.17} & 26.21 & \multirow[t]{2}{*}{5.65} & 26.04 & \multirow[t]{2}{*}{6.37} & \multirow[t]{2}{*}{0.29} & \multirow[t]{2}{*}{.38} \\
\hline & sten 7 & & sten 7 & & sten 7 & & & \\
\hline
\end{tabular}

Note. $M=$ arithmetic mean; $S D=$ standard deviation; $C L=$ confidence level; $\mathrm{RS}=$ raw score. Source: authors' research.

The analysis of the data presented in the Table 4 indicates medium scores on support received from the partner. There was a significant difference between husbands' and wives' scores $(\mathrm{t}=-1.67, \mathrm{p}<.05)$ - women rated the support received from their husbands higher than men rated the support received from their wives.

Scores on the partner's perceived commitment were low (sten 4) and scores on depreciation experienced from the partner were high (sten 7).

The analysis of the results presented in the Table 5 showed that the scores on support received from the partner were medium bordering on low (both in men and in women). 
Table 5. Evaluation of Partner Behaviors by Spouses Brought Up in Single-Parent Families: Differences Between Men and Women

\begin{tabular}{|c|c|c|c|c|c|c|c|c|}
\hline \multirow[b]{2}{*}{ KKM scales } & \multicolumn{2}{|c|}{ Men } & \multicolumn{2}{|c|}{ Women } & \multicolumn{2}{|c|}{ Total group } & \multirow{2}{*}{$\begin{array}{c}\text { Student's } \\
t\end{array}$} & \multirow[t]{2}{*}{ CL } \\
\hline & $M$ & $S D$ & $M$ & $S D$ & $M$ & $S D$ & & \\
\hline \multirow{2}{*}{$\begin{array}{l}\text { Support - RS } \\
\text { Sten scores }\end{array}$} & 38.9 & \multirow[t]{2}{*}{9.25} & 40.37 & \multirow[t]{2}{*}{2.77} & 39.69 & \multirow[t]{2}{*}{6.59} & \multirow[t]{2}{*}{-1.27} & \multirow[t]{2}{*}{.10} \\
\hline & sten 5 & & sten 5 & & $\begin{array}{l}\text { sten } \\
4 / 5\end{array}$ & & & \\
\hline \multirow{2}{*}{$\begin{array}{l}\text { Commitment - RS } \\
\text { Sten scores }\end{array}$} & 26.0 & \multirow[t]{2}{*}{4.51} & 25.96 & \multirow[t]{2}{*}{2.66} & 25.98 & \multirow[t]{2}{*}{3.61} & \multirow[t]{2}{*}{0.06} & \multirow[t]{2}{*}{.47} \\
\hline & sten 3 & & sten 3 & & sten 3 & & & \\
\hline \multirow{2}{*}{$\begin{array}{l}\text { Depreciation - RS } \\
\text { Sten scores }\end{array}$} & 23.9 & \multirow[t]{2}{*}{5.99} & 29.68 & \multirow[t]{2}{*}{10.57} & 27.03 & \multirow[t]{2}{*}{9.21} & \multirow[t]{2}{*}{-3.75} & \multirow[t]{2}{*}{.0001} \\
\hline & sten 6 & & sten 8 & & sten 7 & & & \\
\hline
\end{tabular}

Note. $M=$ arithmetic mean; $S D=$ standard deviation; $\mathrm{CL}=$ confidence level; $\mathrm{RS}=$ raw score. Source: authors' research

The participants scored low on their partners' perceived commitment to marital communication; both husbands and wives critically evaluated the level of their partners' commitment (sten 3). Spouses' scores on the Depreciation scale ranged from sten 6 to sten 8 , indicating a tendency to manifest verbal aggression towards the partner and a desire to control him or her; such scores may also indicate a lack of respect for the partner's dignity. On this scale there was a significant difference between men and women $(t=-3.75, p<$ .0001), with women reporting a higher level of depreciation experienced from the partner (sten 8).

Table 6. Differences Between Spouses Raised in Nuclear and Single-Parent Families in the Evaluation of Partner Behaviors

\begin{tabular}{|c|c|c|c|c|c|c|c|}
\hline \multirow[t]{2}{*}{ Group } & \multirow[b]{2}{*}{ KKM scales } & \multicolumn{2}{|c|}{ Nuclear families } & \multicolumn{2}{|c|}{ Single-parent families } & \multirow{2}{*}{$\begin{array}{c}\text { Student's } \\
t\end{array}$} & \multirow[t]{2}{*}{$\mathrm{CL}$} \\
\hline & & $M$ & $S D$ & $M$ & $S D$ & & \\
\hline \multirow{3}{*}{$\stackrel{\tilde{D}}{\Sigma}$} & Support & 39.21 & 7.51 & 38.9 & 9.25 & 0.21 & .42 \\
\hline & Commitment & 27.12 & 5.02 & 26.0 & 4.51 & 1.32 & .09 \\
\hline & Depreciation & 26.21 & 7.17 & 23.9 & 5.99 & 1.96 & .03 \\
\hline \multirow{3}{*}{$\begin{array}{l}\text { च } \\
\text { हू } \\
3\end{array}$} & Support & 41.28 & 7.48 & 40.37 & 2.77 & 0.96 & .17 \\
\hline & Commitment & 27.53 & 4.88 & 25.96 & 2.66 & 2.41 & .008 \\
\hline & Depreciation & 26.21 & 5.65 & 29.68 & 10.57 & -2.78 & .003 \\
\hline \multirow{3}{*}{ 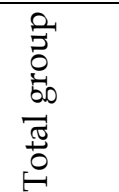 } & Support & 40.32 & 7.54 & 39.69 & 6.59 & 0.73 & .23 \\
\hline & Commitment & 27.34 & 4.94 & 25.98 & 3.61 & 2.60 & .005 \\
\hline & Depreciation & 26.04 & 6.37 & 27.03 & 9.21 & -1.05 & .15 \\
\hline
\end{tabular}

Note. $M=$ arithmetic mean; $S D=$ standard deviation; $C L=$ confidence level. Source: authors' research 
The data presented in Table 6 indicate that there were significant differences between men raised in nuclear and single-parent families in depreciation experienced from the spouse $(t=1.96, p<.03)$. Its level was higher in the group of men brought up in nuclear families (which means that they were either more critical or prepared to put up with more from their wives). Husbands raised in single-parent families evaluated their wives more favorably on this dimension.

We found significant differences also between women raised in nuclear and singleparent families in the evaluation of their husbands' commitment to communication $(t=2.41$, $\mathrm{p}<.008$ ), with wives raised in nuclear families scoring higher. A statistically significant difference existed also between wives raised in nuclear and single-parent families in the level of depreciating behavior they experienced from their husbands $(t=-2.78, p<.003)$; women brought up in single-parent families experienced such humiliating behaviors from their partners more often.

In the comparison of scores between the total groups, only the difference in the partner's perceived commitment turned out to be significant $(t=2.60, \mathrm{p}<.005)$, with spouses raised in nuclear families scoring higher.

\section{Conclusion}

The research results presented above leads to the conclusion that there are two pictures of communication in marriage, as there is no correspondence between self-reported behaviors and the evaluation of partner's behaviors. Spouses evaluate their contribution to marital communication as medium, and at the same time they judge their partners' contribution critically; this is the case particularly for commitment to marital communication and for depreciating the partner.

One can also conclude that communication between spouses raised in single-parent families is of lower quality than communication between spouses brought up in nuclear families. As far as self-reported behavior is concerned, higher levels of support and commitment to communication are reported by spouses raised in nuclear families. In partner behavior evaluations, the levels of the spouse's perceived commitment to communication is also higher among participants raised in nuclear families than among those brought up in single-parent families.

Evaluations differ in the case of depreciation experienced from the partner. Its level in men is higher in the group raised in nuclear families, while among women it is higher in the group raised in single-parent families. It should be noted that participants rated the level of their own depreciating behavior towards the partner as medium, while their evaluation of their partners' level of depreciating behavior was higher. The use of communication 
depreciating the partner can contribute to the feeling of dissatisfaction with the relationship (Weryszko, 2020).

The subject of our study seems to be important, as the research conducted by other authors (e.g., Jankowska, 2016; Dakowicz \& Dakowicz, 2021) revealed significant relations between marital communication and satisfaction with marriage. The quality of marriage is perceived as higher if a spouse evaluates both themselves and the other spouse as more supportive and committed to communication and as less depreciative. High scores on depreciation may therefore be a sign of dissatisfaction with marriage and a threat to its stability. The research results reported by Katarzyna Adamczyk (2013) indicate that spouses differ in how they evaluate their own commitment and that of the other spouse. As in our study, women rated their own abilities of creating an atmosphere of intimacy and understanding lower than men did. This study showed, moreover, that when one of the spouses evaluated the other one as supportive, he or she was more often evaluated as supportive too. Commitment ratings follow a similar pattern. Wives consider themselves more supportive than their husbands consider them to be, while husbands' communication is evaluated equally by husbands themselves and by their wives. It is reasonable to suppose that the source of these discrepancies lies in the different upbringing of boys and girls (Schaffer, 2021). In the case of women more attention is devoted to empathy and supportive behaviors, which is why they may rate themselves higher than their husbands rate them on the support they provide.

\section{Bibliography:}

Adler, R.B., Rosenfeld, L.B., \& Proctor II, R.F. (2018). Relacje interpersonalne. Proces porozumiewania się [Interplay: The process of interpersonal communication], Poznań: Dom Wydawniczy Rebis.

Anderson, S.A., \& Sabatelli, D.B. (1999). Attachment in adolescence, (in:) J. Cassidy \& P. Shaver (eds.), Handbook of attachment, 319-335, New York: Guilford Press.

Adamczyk, K. (2013). Inteligencja emocjonalna i system wartości małżonków a ich komunikacja interpersonalna [Spouses' emotional intelligence and system of values and their interpersonal communication], Kwartalnik Naukowy Fides et Ratio, 2 (13), $72-$ 101.

Bajkowski, T. (2017). System rodzinny w przestrzeni międzykulturowej [The family system in the cross-cultural space]. Pogranicze, Studia Społeczne, 30, 167-180.

Beattie, G., \& Ellis, A. (2017). The psychology of language and communication. London: Routledge.

Bocakova, O., \& Kubickova, D. (2013). Rodzina i autorytety w niej funkcjonujące [The family and the authorities functioning in it], (in:) D. Łyżewska (ed.), Autorytet w wychowaniu $i$ 
edukacji [Authority in upbringing and education], 169-177, Józefów: Alcide De Gasperi University of Euroregional Economy in Jozefów.

Braun-Gałkowska, M. (1992). Psychologiczna analiza systemów rodzinnych osób zadowolonych $i$ niezadowolonych z matżeństwa [Psychological analysis of the family systems of people satisfied and dissatisfied with marriage], Lublin: Wydawnictwo KUL.

Brągiel, J. (2017). Zaniedbanie jako kategoria przemocy - przejawy i konsekwencje doświadczane przez dziecko [Neglect as a category of violence: The symptoms and consequences experienced by the child], (in:) B. Górnicka (ed.), Zaniedbanie dziecka: wybrane aspekty zjawiska [Child neglect: Selected aspects of the phenomenon], 17-37, Opole: Wydawnictwo Uniwersytetu Opolskiego.

Brzezińska, A.I., Appelt, K., \& Ziółkowska, B. (2016). Psychologia rozwoju człowieka [The psychology of human behavior], Sopot: GWP.

Burkacka, I. (2017). Monoparentalność, wielorodzina i rodzina zrekonstruowana. Współczesne nazwy modeli życia rodzinnego [Monoparentality, multi-family, and reconstructed family: Contemporary names of models of family life], Artes Humanae, 2, 61-94, http:/ / dx.doi.org/10.17951/arte.2017.2.61

Celmer, Z. (1989). Małżeństwo [Marriage], Warsaw: Państwowy Zakład Wydawnictw Lekarskich.

Dakowicz, L., \& Dakowicz, A. (2021). Jakość komunikacji małżeńskiej małżonków o wyższym i niższym poziomie zadowolenia ze swojego związku [The quality of marital communication of spouses with a higher and lower level of satisfaction with their relationship], Kwartalnik Naukowy Fides at Ratio, 46(2), 129-141, https://doi.org/10.34766/fetr.v46i2.797.

Danielewicz-Mucha, D. (1995). Rozwój indywidualny dziecka a stosunki z rodzicami [The child's individual development and relations with parents], (in:) J. Trempała (ed.), Rozwijajacy się czlowiek w zmieniajacym się świecie [The developing person in the changing world], 317-329), Bydgoszcz: Wydawnictwo Uczelniane WSP.

de Barbaro, N. (2020). Struktura rodziny [Family structure], (in:) B. de Barbaro (Ed.), Wprowadzenie do systemowego rozumienia rodziny [Introduction to a systemic understanding of the family], 45-55, Kraków: Wydawnictwo UJ.

DeVito, J.A. (2019). The interpersonal communication book (15th ed.), Boston: Pearson Education.

Drożdżowicz, L. (2020). Ogólna teoria systemów [General systems theory], (in:) B. de Barbaro (ed.), Wprowadzenie do systemowego rozumienia rodziny [Introduction to a systemic understanding of the family], 9-17, Kraków: Wydawnictwo UJ.

Elżanowska, H. (2012). Międzypokoleniowa transmisja wartości w rodzinie [Intergenerational transmission of values in the family], Studia z Psychologii w KUL, 18, 97-114. 
Duda, M. (2017). Dom rodzinny - między tradycją a współczesnością [Family home: Between tradition and the present day], Studia Socialia Cracoviensia, vol. 9, 2 (17), 2535, http://dx.doi.org/10.15633/ssc.2453.

Farnicka, M. (2016). W poszukiwaniu uwarunkowań transmisji międzypokoleniowej znaczenie pełnionej roli rodzinnej w kontynuowaniu wzorów rodzicielstwa [In search of the determinants of intergenerational transmission of values: The significance of the family role in perpetuating the patterns of parenthood], Psychologiczne Zeszyty Naukowe, 1, 11-35.

Franczyk, E. (2021). Osoba starsza a kryzys we współczesnej rodzinie w ujęciu systemowym [The older adult and the crisis in the contemporary family: A systemic perspective], Horyzonty Wychowania, vol. 20, 53, 61-71.

Galvin, K. M., Braithwaite, D. O., \& Bylund C. L. (2015). Family communication: Cohesion and change (9th ed.), London and New York: Routlegde Taylor \& Francis Group.

Gawda, K. (2018). Rodzina z jednym rodzicem jako środowisko wychowawcze [Singleparent family as an educational environment], Teologia i Człowiek, 3, 141-152.

Grzesiuk, L., \& Jakubowska, U. (2005). Terapia systemowa [Systemic therapy], (in:) L. Grzesiuk (ed.), Psychoterapia. Teoria [Psychotherapy: Theory], 189-197, Warsaw: Wydawnictwo Eneteia.

Jakubiak, K., \& Nawrot-Borowska, M. (2016). Rodzina polska w XIX wieku jako środowisko wychowawcze i jej funkcja edukacyjna [The Polish family in the 19th century as an upbringing environment and its educational function], Studia Paedagogica Ignatiana, 2, $15-46$.

Jankowska, M. (2015). Wychowanie jako system wzajemnych oddziaływań rodziców i dzieci [Upbringing as a system of bidirectional parent-child influences], Kwartalnik Naukowy Fides et Ratio, 1 (21), 5-33.

Jankowska, M. (2016). Komunikacja pomiędzy małżonkami a ocena jakości związku małżeńskiego [Communication between spouses and self-reported marriage quality], Kwartalnik Naukowy Fides et Ratio, 4 (28), 119-139.

Józefik, B. (2020). Wokół problematyki władzy w rodzinie i w terapii rodzin [On the problems of power in the family and in family therapy], Psychiatria Polska, 54 (4), 777789.

Kalinowski, S., \& Jabłońska-Porzuczek, L. (2016). Ubóstwo rodzin monoparentalnych w Unii Europejskiej [The poverty of single-parent families in the European Union]. Prace Naukowe Uniwersytetu Ekonomicznego we Wrocławiu. Sytuacja rodzin i polityka rodzinna w Polsce po dekadzie członkostwa w Unii Europejskiej [Research Studies of the Wrocław University of Economics and Business. The situation of families and pro-family policy in Poland after a decade of membership in the European Union], 438, 32-46. 
Kaźmierczak, M., \& Plopa, M. (2008). Kwestionariusz Komunikacji Małżeńskiej KKM. Podręcznik [Communication in Marriage Questionnaire (KKM): A manual], Warsaw: Wydawnictwo VIZJA Press \& IT.

Khezri, Z., Hassan, S.A., \& Nordin, M.H.M. (2020). Factors affecting marital satisfaction and marital communication among marital women: Literature of review, International Journal of Academic Research in Business and Social Sciences, 10(16), 220-236, http:/ /dx.doi.org/10.6007/IJARBSS/v10-i16/8306.

Koprowicz, A., Gumowska, I., \& Piotrów, E. (2018). Percepcja rodzin generacyjnych o różnej strukturze u kobiet i mężczyzn w okresie późnej adolescencji [The perception of families of origin with different structures in women and men in late adolescence], Kwartalnik Naukowy Fides at Ratio, 34 (2), 207-226.

Krasiejko, I. (2018). Polityka rodzinna i praca socjalno-wychowawcza jako działania na rzecz rodzin niepełnych [Family policy and socio-educational work as actions for the benefit of single-parent families], Praca Socjalna, 33(4), 88-108.

Kuzdak, M. (2018). Niepełna rodzina jako zaburzenie prawidłowego funkcjonowania struktur rodzinnych [The single-parent family as a disturbance in the proper functioning of family structures], Acta Scientifica Academiae Ostroviensis, 1, 126-142.

Liberska, H. (1998). Wybrane aspekty psychologicznego funkcjonowania młodzieży wychowywanej $\mathrm{w}$ rodzinach pełnych $\mathrm{i}$ niepełnych [Selected aspects of the psychological functioning of adolescents in nuclear and single-parent families], Roczniki Socjologii Rodziny, 10, 231-246.

Mackay, R. (2005). The impact of family structure and family change on child outcomes: A personal reading of the research literature, Social Policy Journal of New Zealand, 24, 111131.

Marek-Zborowska, B. (2018). Problemy samotnych matek [The problems of single mothers], (in:) E. Grudziewska \& M. Mikołajczyk (eds.), Wybrane problemy społeczne. Teraźniejszość - Przyszłość [Selected social problems: The present - the future], 32-46, Warsaw: Wydawnictwo Akademii Pedagogiki Specjalnej.

Margasiński, A. (2015). Teoria i wybrane modele systemów rodzinnych [Theory and selected models of family systems], (in:) A. Margasiński (ed.), Rodzina w ujęciu systemowym. Teoria $i$ badania [A systemic perspective on the family: Theory and research], 6-32, Warsaw: Psychological tests Laboratory of the Polish Psychological Association.

Matyjas, B. (2015). Dzieciństwo osamotnione w rodzinie niepełnej. Raport z badań [Lonely childhood in a single-parent family: A research report], Kwartalnik Pedagogiczny, 1, 207-224.

McKay, M., Davis, M., \& Fanning, P. (2019). Sztuka skutecznego porozumiewania sie [Messages: The communication skills book], Sopot: GWP. 
Molesztak, A. M. (2017). Dynamika współczesnej rodziny [The dynamics of the contemporary family], Horyzonty Wychowania, 16 (38), 73-88, https://doi.org/10.17399/HW.2017.163805.

Mulac, A. (2009). The gender-linked language effect: Do language differences really make a difference? (in:) K. Dindia \& D. Canary (eds.), Sex differences and similarities in communication (2nd ed.), 211-231, New York \& London: Lawrence Erlbaum Associates.

Nowak, B. M. (2018). (Nie)bezpieczna rodzina - kalejdoskop (dys)funkcji [The (in)secure family: A kaleidoscope of (dys)functions], Nauki o Wychowaniu, Studia interdyscyplinarne, (9), 33-55, https:// doi.org/10.18778/2450-4491.09.04.

Nurhayati, S.R., Faturochman, F., \& Helmi, F.A. (2019). Marital quality: A conceptual review, Buletin Psikologi, 27(2), 109-124, https://doi.org/10.22146/buletinpsikologi.3769.

Olearczyk, T.E. (2008). Sieroctwo i osamotnienie: pedagogiczne problemy kryzysu wspótczesnej rodziny [Orphanhood and loneliness: Pedagogical problems concerning the crisis of the contemporary family], Kraków: Wydawnictwo Ignatianum.

Ogonowska, A. (2018). Psychologia mediów i komunikowania. Wprowadzenie [The psychology of the media and communication: An introduction], Kraków: Wydawnictwo Impuls.

Osior-Szot, K. (2018). Różnice w stylach komunikacyjnych kobiet i mężczyzn [Differences in communication styles between men and women], Media - Biznes - Kultura. Dziennikarstwo i Komunikacja Społeczna, 5, 171-184.

Ostafińska-Molik, B., \& Wysocka, E. (2016). Rodzina w doświadczeniach młodzieży gimnazjalnej w kontekście przemian rodziny współczesnej - refleksja teoretyczna i empiryczne egzemplifikacje [Middle school students' experience of family in the context of changes of the contemporary family: Theoretical reflection and empirical exemplifications], Przegląd Pedagogiczny, 1, 56-76.

Parzątka-Lipińska, K.J. (2019). Funkcjonowanie dziecka z rodziny niepełnej w szkole [The functioning of a child from a single-parent family at school], Pedagogika Rodziny, 4, 6170.

Pearson, C.J., West, R.L., \& Turner, L.H. (1995). Gender and communication, Dubuque, IA: William C. Brown.

Plopa, M. (2008). Więzi w matżeństwie i rodzinie. Metody badań [Relationships in marriage and in the family: Research methods], Kraków: Wydawnictwo Impuls.

Plopa, M., \& Połomski, P. (2010). Kwestionariusz Relacji Rodzinnych. Wersje dla młodzieży. Podręcznik [The Family Relations Questionnaire: Versions for adolescents], Warsaw: VIZJA Press \& IT.

Przybysz-Zaremba, M. (2017). Kontrola rodzicielska a zachowania ryzykowne dzieci i młodzieży [Parental control and risky behaviors of children and adolescents], Pedagogika Społeczna, 4(66), 133-144. 
Rostowska, T. (2008). Małżeństwo, rodzina, praca a jakość życia [Marriage, family, work, and quality of life], Kraków: Wydawnictwo Impuls.

Ryś, M. (2001). Metody badań struktury rodziny pochodzenia i rodziny własnej [The methods of research on the structure of the family of origin and the current family], Warsaw: Centrum Metodyczne Pomocy Psychologiczno-Pedagogicznej MEN.

Ryś, M. (2004). Jakość związku małżeńskiego a poziom bliskości małżonków i sposoby rozwiązywania przez nich konfliktów [Marriage quality as related to the level of intimacy between spouses and their ways of solving conflicts], Studia Psychologica, 5, $57-67$.

Satir, V. (2000). Rodzina. Tu powstaje człowiek [The new peoplemaking], Gdańsk: GWP.

Segal, D.L., Qualls, S. H., \& Smyer, M.A. (2018). Aging and mental health (3rd ed.), Hoboken, NJ: Wiley-Blackwell.

Schaffer, R. H. (2021). Psychologia dziecka [Introducing child psychology], Warsaw: PWN.

Schrodt, P., \& Scruggs, X. (2020). Young adults' shared family identity with parents as a function of family communication patterns, Communication Reports, 34 (1), 14-25, https://doi.org/10.1080/08934215.2020.1859573.

Segrin, C., \& Flora, J. (2019). Family communication (3rd ed.), New York, NY: Routledge.

Sitarczyk, M. (1995). Transmisja międzypokoleniowa postaw rodzicielskich

[Intergenerational transmission of parental attitudes], (in:) Z. Gaś (ed.), Psychologia wychowawcza stosowana. Wybrane zagadnienia [Applied educational psychology:

Selected issues], 117-129, Lublin: Wydawnictwo UMCS.

Slany, K. (2002). Alternatywne formy życia matżeńsko-rodzinnego w ponowoczesnym świecie [Alternative forms of marital and family life in the postmodern world], Kraków: Wydawnictwo NOMOS.

Statistics Poland (GUS) (2020). Rocznik demograficzny [The demographic yearbook of Poland 2020]. Access: July 5, 2021, at http://www.stat.gov.pl/obszary-tematyczne/rocznikistatystyczne/roczniki-statystyczne/rocznik-demograficzny-2020,3,14.html.

Strużyńska, A. (2020). Rodzina jako podstawowe środowisko wychowawcze [Family as the basic educational environment], (in:) J. Zimny (ed.), Rodzina naturalna, duchowa, społeczna [The natural, spiritual, and social family], 188-198, Wrocław: General Tadeusz Kościuszko Military Academy of Land Forces.

Szewczuk, K. (2010). Struktura rodziny a proces wychowania dzieci i młodzieży w rodzinie [Family structure and the upbringing of children and adolescents in the family]. In A. Błasiak \& E. Dybowska (Eds.), Wybrane zagadnienia pedagogiki rodziny [Selected issues of family pedagogy], 143-166, Kraków: Wydawnictwo WAM.

Szczęsna, A., \& Przybyła-Basista, H. (2019). Marital dialogue as a constructive response to dissatisfaction in marriage and its predictors, Scientific Papers of Silesian University of 
Technology, Organization and Management, 141, 405-419,

http:/ /dx.doi.org/10.29119/1641-3466.2019.141.31.

Tannen, D. (1990). Gender differences in topical coherence: Creating involvement in best friends' talk. Discourse Processes, 13 (1), 73-9, https://doi.org/10.1080/01638539009544747.

Tench, R., Topić, M., \& Moreno, A. (2017). Male and female communication, leadership styles and the position of women in public relations, Interactions: Studies in Communication $\mathcal{E}$ Culture, 8 (2-3), 231-248, https:// doi.org/10.1386/iscc.8.2-3.231_1.

Tryjarska, B. (2003). Komunikowanie między małżonkami niezadowolonymi ze związku [Communication between spouses dissatisfied with marriage], Nowiny Psychologiczne, 4, 5-14.

Walęcka-Matyja, K., \& Janicka, I. (2021). Rodzina jako wartość. Analiza psychologiczna wartości rodzinnych [Family as a value: A psychological analysis of family values], Łódź: Wydawnictwo Uniwersytetu Łódzkiego.

Walęcka-Matyja, K. (2014). Role i funkcje rodziny [The roles and functions of the family]. In I. Janicka \& H. Liberska (Eds.), Psychologia rodziny [The psychology of the family], 95114). Warsaw: PWN.

Wampler, K.S., \& Patterson, J.E. (2020). The importance of family and the role of systemic family therapy, (in:) K.S. Wampler \& L.M. McWey (eds.), The handbook of systemic therapy (vol. 1), 1-32, Hoboken, NJ: Wiley-Blackwell.

Weryszko, M. (2020). Miłość małżeńska - uwarunkowania powodzenia fundamentalnej relacji $\mathrm{w}$ rodzinie [Marital love: The determinants of the success of fundamental family relationship], Kwartalnik Naukowy Fides Et Ratio, 41 (1), 129-143.

Wilk, J. (2016). Pedagogika rodziny [Pedagogy of the family], Lublin: Wydawnictwo Episteme.

Wolska-Długosz, M. (2016). Samotne rodzicielstwo - blaski i cienie. Próba syntezy [Single parenting: Good and bad sides. An attempt at a synthesis], Scientific Bulletin of Chetm Section of Pedagogy, 2, 57-66.

Wróbel, K. (2021). Specyfika komunikacji w systemie rodzinnym [The specific nature of communication in the family system], Kwartalnik Naukowy Fides at Ratio, 46 (2), 118128, https://doi.org/10.34766/fetr.v46i2.809.

Zalewska, S.L. (2017). Values in a modern family: Between declaration and deed, Society Register, 1 (1), 183-198, https:/ / doi.org/10.14746/sr.2017.1.1.15. 